\title{
Implementation Of E-Government In Kelurahan Of Tanjungpinang City (Study on SIMDA BMD application)
}

\author{
Shahril Budiman \\ Government Science Department \\ STISIPOL Raja Haji \\ Tanjungpinang, Kepulauan Riau, Indonesia \\ shahril2204@gmail.com / shahril@stisipolrajahaji.ac.id
}

Zamzami A. Karim

Government Science Department

STISIPOL Raja Haji

Tanjungpinang, Kepulauan Riau, Indonesia zamikareem@gmail.com

Eki Efriyansyah

STISIPOL Raja Haji

Tanjungpinang, Kepulauan Riau, Indonesia

ekiefriyansyah@gmail.com

\author{
Junriana \\ Government Science Department \\ STISIPOL Raja Haji \\ Tanjungpinang, Kepulauan Riau, Indonesia \\ rianazamzam@yahoo.com \\ Raja Abumanshur Matridi \\ Public Administration Department \\ STISIPOL Raja Haji \\ Tanjungpinang, Kepulauan Riau, Indonesia \\ matridi_aeksalo@yahoo.com
}

\begin{abstract}
E-government is the utilization of information technology used to speed up the implementation of the government in improving the accessibility of the data presented in a timely, accurate urban villages for employees without requiring any intermediary information systems, the implementation of applications e-government of urban villages in Tanjungpinang use a type G2G (government-to-government), where this type have a need to interact between one government and other Governments in order to increase of cooperation and work processes Relating SIMDA BMD (Management Information System Regional Property). This study aims to look at the implementation and inhibiting factors in the application of e-government in Tanjungpinang urban villages. Researchers used qualitative research methods. The Data collected in this study uses interviews. The results Showed that there were already base of implementation e-government in Sub Tanjungpinang through the application of SIMDA BMD applications (Management Information System Regional Property). In general, the implementation of applications egovernment of urban village is optimal, it is seen from the villages helped in facilitating good clerks Administration of procurement, procurement planning in Sub Tanjungpinang. In the application of operating BMD SIMDA there are constraints of the which the export menu inpor the data can not be used Because the application is still offline.
\end{abstract}

Keywords—component; formatting; style; styling; insert

\section{INTRODUCTION}

The development of information and communication technology (ICT) to change people's lives, especially the changing relationship between the characteristics of human relationships, business, and change the relationship between government to government and government to citizen. Egovernment is a process of using information technology as a tool to help run the government system more efficiently. Therefore, there are two main things in the sense egovernment that the first is the use of information technology (one of which is the Internet) as a tool, and, second, the purpose of exploiting government can run more efficiently.

According to Budiman S, et al (2017: 113) in the Proceedings of the International Conference states that: Digital age has delivering impact into many sectors Whether private of government sectors, the which is oriented on building organization Effectively, easy way of connectivity and customer / public service statisfaction were create a lot of system changing rapidly.

From the quote above can be explained that the benefits of the digital age has an impact to many sectors both public and private sectors, development oriented organization effectively, ease of connectivity in the process organization government and customer satisfaction / public services that make a lot of system changes rapidly. In the instructions of the President of the Republic of Indonesia Number 3 of 2003 on National Policy and Strategy Development of E-Government mentioned about matters into consideration the implementation of E-Government in Indonesia, among others, 
firstly that advances in communications technology and information rapidly and the potential for their use widespread, opportunities for access, management and utilization of information in large volumes quickly and accurately. Second, that the use of information and communication technologies in the process of governance E-Government will improve the efficiency, effectiveness, transparency, and accountability in governance. Thirdly, That to conduct good governance (good governance) and improving public services effective and efficient policies and strategies for developing e-Government.

Implementation of E-Government in the Village of Tanjungpinang using a type of Government to Government. where Government to Government who have a need to interact between one government and other governments in order to increase cooperation and work processes related to finance, procurement, letters and demographic data. Villages in Tanjungpinang alredy using communication technology-based applications offline directly related to government agencies in Tanjungpinang one application SIMDA BMD (Regional Management Information System Regional Property) associated with BPKAD.

Applications SIMDA BMD is an application system offline used to process local refineries owned goods (BMD) automatically by utilizing electronic data processing. This application is programmed automatically for the planning, procurement, elimination of items and accounting administration regional goods, capital expenditure data input area. With the implementation and development of applications based e-government applications such sofwere already owned every village Tanjungpinang is a first step in efforts to support the government's performance-based electronics and also can produce information that is comprehensive, precise and accurate to the management of the government, could also facilitate relations administration between local government offices effectively and efficiently.

Through the development and implementation of egovernment to restructure the management system and work processes within government agencies, especially the Village Tanjungpinang performing the function of usefulness and usability of this application. With the passage of applications based E-Government in every village it is expected that all the activities of government organizations can be conducted electronically to facilitate the work of employees and time spent is also very fast along with the policy functions and relationship administration between government offices, in practice the concept of E-Government is shared responsibility, meaning that not only the government but also public participation (share goals). Mulyono (2011: 76).

In the application of applications based e-government in the village of Tanjungpinang there are obstacles in operation in its implementation due to barriers SIMDA application BMD and Financial SIMDA still offline, the data is still working mengimput twice both in the village and BPKAD. the application of existing BMD SIMDA inpor and export options for the data but cannot be used properly, whereas the urban village to import data must use the services to the department flasdisk inform to BPPKD.modified in MS Word 2007 and saved as a "Word 97-2003 Document" for the PC, provides authors with most of the formatting specifications needed for preparing electronic versions of their papers. All standard paper components have been specified for three reasons: (1) ease of use when formatting individual papers, (2) automatic compliance to electronic requirements that facilitate the concurrent or later production of electronic products, and (3) conformity of style throughout a conference proceedings. Margins, column widths, line spacing, and type styles are built-in; examples of the type styles are provided throughout this document and are identified in italic type, within parentheses, following the example. Some components, such as multi-leveled equations, graphics, and tables are not prescribed, although the various table text styles are provided. The formatter will need to create these components, incorporating the applicable criteria that follow.

\section{RESEARCH QUESTIONS}

E-Government is the first step in efforts to support the government's performance-based electronics in order to maintain and improve the quality of urban employees work in Sub Tanjungpinang. The identification of the formulation of the problem as follows:

1. How SIMDA BMD Application Implementation village in Tanjungpinang?

2. What Factors Inhibiting SIMDA BMD in implementation and application of village at Tanjungpinang?

\section{LITERATURE REVIEW}

\section{Information Technology}

According to the Information Technology Association of America (ITAA) in Sutarman (2009: 13), information technology is the study, design development, implementation, support or management of computer-based information systems. Information Technology (IT) utilizing electronic computers and computer software to convert, store, protect, process, transmit, and securely retrieve information. Likewise the above definition, Luke in Abdul Kadir (2007: 13) states that information technology is all forms of technology applied to process and transmit information in electronic form. Microcomputer, mainframe computers, barcode readers, transaction processing software, spreadsheet software, communications equipment and networks, is an example of information technology.

\section{Role of Information Technology}

Broadly speaking, one can say that, first, information technology replaces human role. In this case, information technology automation to a task or process. Second, strengthen the role of human technology, by presenting information on a task or process. Third, information technology plays a role in the restructuring of the role of human beings, where technology plays in making changes to a set of tasks or processes (Abdul Kadir, 2007: 15). The reality machines replace human tasks of a role in providing the 
easiness. On the other hand, without the participation of man, these machines can not be operated. So it can be concluded that the application of information technology is very important in all aspects of human life, including for businesses and public service activities.

\section{Management Information System}

Management Information System formed by three words, namely systems, information and management. According Sutanta (2003: 3) system is a "set of things or events or elements, or subsystems that mutual cooperation or associated with certain ways so as to form a single unit to perform a function in order to achieve a goal." Azhar Sutanto (2007: 46) defines information as "the result of data management that gives meaning and benefits". and management as "an organized team within the organization to achieve the goals and objectives to be achieved by an organization".

According Mcleod (2010: 11) management information system (MIS) is a computer-based system that provides information for those users who have the same needs". The management information system is also a system that was created to carry out data processing to be used by an organization. Further Kumorotomo (2004: 9) explains that "the elements of which represent a general information system is input (input), processing (processing) and output (output)".

Understanding of management information systems (MIS) above can be explained that the management information system (MIS) is a system that provides to the management of organizational data and information relating to the implementation of organizational tasks.

\section{Electronic Government}

In his book entitled Building e-Government applications, Indrajit (2002: 3), to mention various definitions of Electronic Government (e-government) put forward by both government agencies and non-governmental. The World Bank Group defines electronic government (e-government) associated with the use of information technology (such as a wide area network, Internet and mobile computing) by the government organization that has the ability to form relationships with citizens, businesses and other organizations in the government.

E-Government can easily be interpreted as a procedure for electronic government. Meanwhile, in a broad sense, the EGovernment is the use of information technology and government agencies to improve services to the public. The goal is to improve service to the community with emphasis on the principles of transparency and equal rights for citizens to access services (www.Deptan.go.id). Electronic Government or commonly known as E-Government actually has a lot of definitions put forward by experts as well as certain institutions.

World Bank Group (2001) states the E-Government Refers to the use by government agencies of information technologies (such as Wide Area Networks, the Internet, and mobile computing) that have the ability to transform relations with citizens, businesses, and other arms of government, Reviews These technologies can serve a variety of different ends: better delivery of government services to citizens, improve interactions with business and industry, citizen empowerment throught access to information, or more efficient government management.

The idea is the use of information technology by government officials was able to improve relations with citizens, businesses and with other government itself. TI provides many benefits in the field of improvement of government services; improve interaction with business and industry, as well as the empowerment of citizens through government management information or to make an effective and efficient.

\section{E-Government Applications}

In building e-government application systems needed standardization of application system development requirements that will ensure that the inter-system communication can be performed by any vendor system developers. Here is Standard System Requirements Applications must be met by each application system eGovernment by Blueprint (blueprint) System Application EGovernment To Institute of Local Government as follows:

\section{a. Reliable}

Ensure that the application system will be able to walk with reliable, robust to errors of data entry, operating system changes and bug free.

\section{b. Interoperable}

Ensure that the application system will be able to communicate and exchange data and information with other application systems to establish a system synergy.

\section{c. Scalable}

Ensure that the application system will be able to be easily upgraded, most notably the addition of new features, additional user and data management capabilities are greater.

\section{d. User Friendly}

Ensure that the application system will be easy to operate with a user interface (user interface) that is commonly applicable in the government and in accordance with its cultural customs and language.

\section{e. Integrateable}

Ensure that the application system has a feature for ease of integration with other application systems, especially for transaction data and information exchange between systems of e-Government applications, both within the local government with other local governments.

\section{Benefits of E-Government}

The benefits obtained with the implementation of egovernment concept for a country according to (Indrajit, 2006: 5), among others:

a. Improving the quality of government services to its stakeholders (community, business, and industry), 
especially in terms of performance effectiveness and efficiency in various fields of life of the state;

b. Improve transparency, control and accountability of governance in order to implement the concept of good corporate governance;

c. Significantly reducing the total cost of administration, relationships, and interactions issued by the government and other stakeholders for the purpose of daily activities;

d. Provide an opportunity for the government to obtain new sources of revenue through its interaction with the parties concerned; and

e. Create a new community environment that can quickly and accurately answer the various problems faced in line with the various global changes and trends that exist; and

f. Empowering communities and other parties as a government partner in the process of policy-making and democratic pubic evenly.

\section{Development of E-Government}

Every change of the potential to cause uncertainty, therefore the development of E-Government need to be drafted and implemented in a systematic way through the stages of realistic and measurable targets, so as to be understood and followed by all parties. Based on the nature of the transaction information and public services provided by the government through information networks, the development of egovernment can be implemented through four (4) levels as follows:

a. Level 1 - Preparations include:

- Making every institution information sites;

- Preparation of human resources;

- Preparation means easy access for example to provide a means of multipurpose community center, cafe, SME-Center, etc;

- Socialization sites for information both internally and to the public.

b. Level 2 - Maturation which include:

- Making interactive public information sites;

- Making the interface of connectedness with other institutions;

c. Level 3 - Stabilization of which include:

- Making public services transaction site;

- Making the interoperability of applications and data with other agencies

\section{d. Level 4 - Utilization include:}

- Making an application for services that are $\mathrm{G} 2 \mathrm{G}$, G2B and G2C integrated.

- Site central and local governments should be gradually increased toward the level - 4 .

- It should be considered that the higher the levels of these sites require supporting management systems, work processes, and transaction information between agencies increasingly complex anyway. Efforts to raise the level of the site without adequate support, would be a failure not only lead to waste, but also lost the confidence of the public.

- To avoid this, it needs to be standardized number of settings

\section{Important Aspects of Successful E-Government Support}

Important Aspects of Successful E-Government Support are currently in various government agencies throughout Indonesia on average have implemented e-government system in accordance with Presidential Decree No. 3 of 2003 on the National Development Strategy and e-Government in Indonesia. In line with this concept, Ayu Aditya Oktavya in his journal, entitled Implementation of Electronic Government (e-Government) In the Tax Office Primary In Service Delivery In Boateng City. Explain important aspects of supporting the success of e-government determinant a number of factors that should be taken into consideration in determining the level of readiness of the region to Implementation e-government are as follows:

a. Telecommunications infrastructure

In the level of implementation, hardware such as computers, networks, and infrastructure will be a very important factor in the implementation of egovernment. Ideally it should available infrastructure that can support targets or the development of egovernment priorities that have been agreed. But pragmatically, should be also taken into consideration the potential and ability or status development of telecommunications infrastructure in the corresponding location.

\section{b. Participation}

Participation is applied to each country differs according to the context and the type of democracy practiced. In general, countries adopt a system of representation. Democracy in representation system emphasizes communication or interaction between society, government and government officials, and increase opportunities for people to participate in the policy-making process in accordance with the aspirations of each. Here we can see things that are important in the process of democracy is participation, including communications. Communication is no flow of information between the actors involved. The most important aspect of the development of e-government is the number of sectors involved and interact in the same or different levels as well as the importance of the democratic process that aims to improve the process of policymaking by increasing the opportunities for participation by all sectors through the distribution of information and communication. 
c. Readiness Human Resources

Human resources is what will be a "major player" or subjects in e-government initiatives are basically the people who work in government agencies. So that the level of competence and expertise of their proximity to greatly affect the performance of the implementation of e-government. The higher level of literacy of Human Resource information technology in government. Getting ready for them in applying the concept of e-government.

d. Availability Fund and Budget (Government support)

Availability and consistency of this budget is a great support to develop e-government that has been applied. Therefore, government support occupy a very important role if government support is not given then ascertained e-government also will not run smooth. although use of information technology should not be analogous to the high funding requirements, but the requirements planning in the budget tends to be limited. Financial constraints in the implementation of e-government could have an effect on the low quality of public service delivery so that the technology based on these conditions the government must always strategy in building a comprehensive e-government network despite limited funding.

e. Legal Instruments

The concept of e-government are closely linked to the creation of business and distribution data / information and intellectual property rights, for example, would be a thing di perlu protected by laws or regulations applicable law. The government should have the legal data card that can guarantee the creation of e-government mechanisms conducive.

\section{RESEARCH METHODOLOGY}

The type of research is that researchers used qualitative research is a research approach that revealed certain social situations to describe reality correctly, in the form of the words based on techniques of collecting and analyzing data on the situation relapse that in earn natural. According to Creswell in Djama'an Statori and Komariah Aan (2012: 24) points out: Qualitative research is an inquiry process of understanding based on methological distinct traditions of inquiry that explore social or human problem. the researcher builds a complex, holistic picture, words analyzes reports detailed views of informants, and conducts the study in a natural setting. That is a qualitative research is a process of inquiry about an understanding based on the traditions for separate methodological traditions; clear checks that roam a social or human problem. researchers build a complex, holistic, examining the words of reports detailing the views of native speakers, and conduct studies in a natural setting. While data collection technique use semi structure interview. According to Sugiyono (2007: 73) semi- structured interviews meant that this type of interview is to determine the problem that is more open, where the village of Tanjungpinang invited to interview the requested opinion, and ideas. In conducting interviews, researchers need to listen carefully and take note of what was stated by the informant.

\section{FINDINGS}

An implementation of E-Government applications in the Village Office in Tanjungpinang intended to identify and describe the success of the implementation of e-government at the village office in the city of Tanjungpinang. The implementation of e-government in the Village of Tanjungpinang use the type of G2G (Government To Government) where Government to Government who have a need to interact between one government and other governments in order to increase cooperation and work processes which do no longer manual but with. This application relates to the procurement of local assets, so as to which has been described previously with dimensions and some of the indicators that will be examined in this study is in accordance with an important aspect of supporting the success of e-government, namely: infrastructure Telecommunications, Human Resources (HR), Participation, government support and tools as well as the Law of the inhibiting factors encountered in the implementation of e-government applications.

\section{Telecomunication infrastructure}

In the implementation level of e-government applications village in Tanjungpinang, hardware such as computers, networks and applications, this infrastructure will be a very important factor in the implementation of e-government based applications. Ideally it should available infrastructure that can support the target or priority e-government implementation villages in Tanjungpinang. But pragmatically, should be also taken into consideration the potential and ability or status telecommunications infrastructure in each village. can be seen in telecom infrastructure and applications in each village in the city of Tanjungpinang below: 
TABLE I. Telecommunications infrastructure village in Tanjungpinang

\begin{tabular}{|c|c|c|c|c|}
\hline \multirow[t]{2}{*}{ No } & \multirow[t]{2}{*}{ Name urban } & \multicolumn{3}{|c|}{ infrastructure Telecommunications } \\
\hline & & $\begin{array}{l}\text { Total } \\
\text { Computer }\end{array}$ & $\begin{array}{l}\text { Type } \\
\text { Connection } \\
\text { Network }\end{array}$ & $\begin{array}{l}\text { Network } \\
\text { Internet }\end{array}$ \\
\hline 1 & $\begin{array}{l}\text { Village Tanjung } \\
\text { Ayun Sakti }\end{array}$ & 10 & Wifi & Speedy \\
\hline 2 & $\begin{array}{l}\text { Village. } \\
\text { Dompak }\end{array}$ & 8 & Wifi & Cyber \\
\hline 3 & $\begin{array}{l}\text { Village. Pinang } \\
\text { Kencana }\end{array}$ & 11 & Wifi & Speedy \\
\hline 4 & $\begin{array}{l}\text { Village. } \\
\text { Tanjungpinang } \\
\text { City } \\
\end{array}$ & 8 & Wifi & Speedy \\
\hline 5 & $\begin{array}{l}\text { Village. } \\
\text { Kampung } \\
\text { Bulang }\end{array}$ & 8 & Wifi & Telkomsel \\
\hline 6 & $\begin{array}{l}\text { Village. Melayu } \\
\text { Kota Piring }\end{array}$ & 10 & Wifi & Speedy \\
\hline 7 & $\begin{array}{l}\text { Village. } \\
\text { Penyengat }\end{array}$ & 6 & Wifi & Speedy \\
\hline 8 & Village. Batu IX & 9 & Wifi & IndieHome \\
\hline 9 & $\begin{array}{ll}\text { Village. } & \text { Air } \\
\text { Raja } & \\
\end{array}$ & 8 & Wifi & Speedy \\
\hline 10 & $\begin{array}{l}\text { Village. } \\
\text { Kamboja }\end{array}$ & 7 & Wifi & Speedy \\
\hline 11 & $\begin{array}{l}\text { Village. } \\
\text { Tanjung Unggat }\end{array}$ & 7 & Wifi & Speedy \\
\hline 12 & $\begin{array}{l}\text { Village. } \\
\text { Kampung Bugis } \\
\end{array}$ & 11 & Wifi & Speedy \\
\hline 13 & $\begin{array}{l}\text { Village. } \\
\text { Senggaran }\end{array}$ & 4 & Wifi & Telkomsel \\
\hline 14 & $\begin{array}{l}\text { Village. } \\
\text { Jang }\end{array}$ & 12 & Wifi & Speedy \\
\hline 15 & $\begin{array}{l}\text { Village. Bukit } \\
\text { Cermin }\end{array}$ & 11 & Wifi & Speedy \\
\hline 16 & $\begin{array}{l}\text { Village. } \\
\text { Tanjungpinang } \\
\text { Timur } \\
\end{array}$ & 9 & Wifi & Speedy \\
\hline 17 & $\begin{array}{l}\text { Village. } \\
\text { Kampung Baru }\end{array}$ & 9 & Wifi & Speedy \\
\hline 18 & $\begin{array}{l}\text { Village. } \\
\text { Tanjungpinang } \\
\text { Barat }\end{array}$ & 10 & Wifi & Speedy \\
\hline
\end{tabular}

Based on table can be described the existing telecommunications infrastructure in sub-districts throughout Tanjungpinang city either from a computer and internet networks are adequate in running applications in the villages in the city of Tanjungpinang.

a. Regional Management Information System Application Regional Property (SIMDA BMD)
Table II. Module Management Information System Application Areas Regional Property (SIMDA BMD)

\begin{tabular}{|c|c|}
\hline Module & LOCAL PROPERTY MANAGEMENT \\
\hline $\begin{array}{l}\text { Function } \\
\text { Application }\end{array}$ & DEPARTMENT \\
\hline Classification & $\begin{array}{l}\text { Form Application: Offline } \\
\text { Type of Service: } \\
\text { Back office "orientation function more } \\
\text { shown to provide relief work that is } \\
\text { government administration, as well as } \\
\text { the functions of official and institutional. } \\
\text { Object Service: G2G }\end{array}$ \\
\hline Function & $\begin{array}{l}\text { This system helps the village in City of } \\
\text { Tanjungpinang in carrying out the task of } \\
\text { procurement planning, use, } \\
\text { administration, maintenance, utilization, } \\
\text { elimination of goods and accounting } \\
\text { items automatically region. } \\
\text { Characterized by a has happened its } \\
\text { mapping item code, asset code, code } \\
\text { shopping in this application. }\end{array}$ \\
\hline Organization & $\begin{array}{l}\text { a. BPKAD (Revenue Management Board } \\
\text { Finance and Asset) } \\
\text { b. Kelurahan Tanjungpinang }\end{array}$ \\
\hline Integration & $\begin{array}{l}\text { SIMDA Application Finance, Financial } \\
\text { Management Module }\end{array}$ \\
\hline $\begin{array}{l}\text { Info: } \\
\text { Additional }\end{array}$ & $\begin{array}{l}\text { Name Application SIMDA BMD } \\
\text { Legal basis: } \\
\text { 1. Kepmendagri No. } 49 \text { of } 2001 \text { on local } \\
\text { goods management information systems. } \\
\text { 2.Permendagri } 19 \text { Year } 2016 \text { on } \\
\text { Guidelines for Regional Property } \\
\text { Management. } \\
\text { Recommendation: } \\
\text { Building information systems in } \\
\text { conducting the affairs of governance } \\
\text { should synergize with the relevant } \\
\text { agencies so that it can make information } \\
\text { quickly and accurately }\end{array}$ \\
\hline
\end{tabular}

Source: Processed Data Application System SIMDA BMD village in Tanjungpinang Based on Blue Print E-Government To Institute for Local Government, 2017

Applications SIMDA BMD Tanjungpinang exist in the Village is an application that directly given by BPKAD Tanjungpinang. This application is already running four (4 years) in every village Tanjungpinang, before the application is no village in Tanjungpinang using Microsoft Excel for the administration and others. Unlike the SIMDA BMD after their application which has benefits for both simplify administration of procurement, procurement planning in Sub Tanjungpinang. In the application perform BMD SIMDA there are constraints which the export menu inpor data cannot be used because the 
application is still offline, seen from the constraints of export problems of data within applications inpor SIMDA in the future BMD then this application should be improved further to be online.

Basically the application SIMDA BMD is a generic application that can be used in general and is applicable anywhere (more spacious). BMD SIMDA application provided by the City of Tanjungpinang. BPKAD has a function to assist the village in Tanjungpinang in carrying out the task of procurement planning, use, administration, maintenance, utilization, elimination of regional goods and accounting items automatically. Characterized by a has mapped the item code, the code assets, expenditures code in this application

FIGURE 1. Initial View SIMDA BMD Application Village in Tanjungpinang

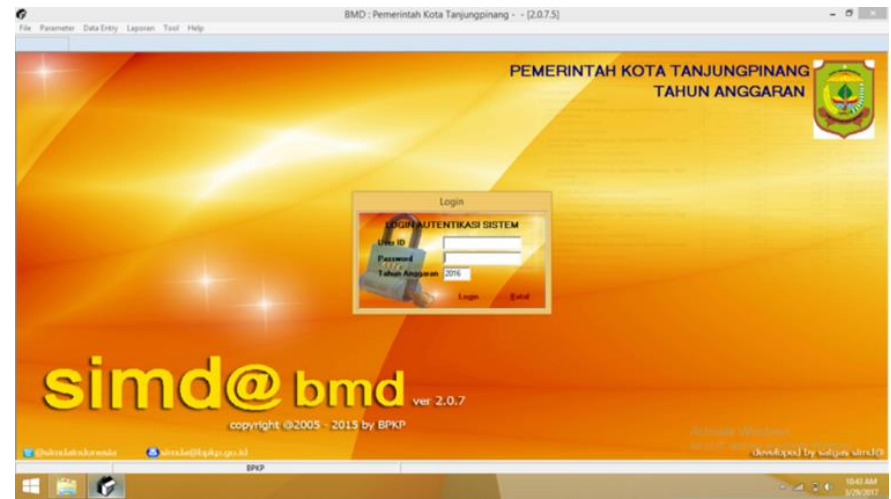

Source: Application SIMDA BMD village in Tanjungpinang, 2017

SIMDA BMD is an offline application system used to process local refineries owned goods (BMD) automatically by utilizing electronic data processing. In the application system are tools in the menu bar application system SIMDA BMD program in the form of files, parameters, data entry, reporting tools and help. BMD SIMDA application program, wherein the application system SIMDA BMD program is already available activities goods activity is no planning, procurement, usage, administration of utilization, maintenance and removal. In SIMDA BMD operation village in Tanjungpinang party applications use this application to administer goods only, can be seen in the picture below regarding the goods in the application SIMDA administration of BMD as following;
FIGURE 2. Implementation of Administration In SIMDA BMD Application

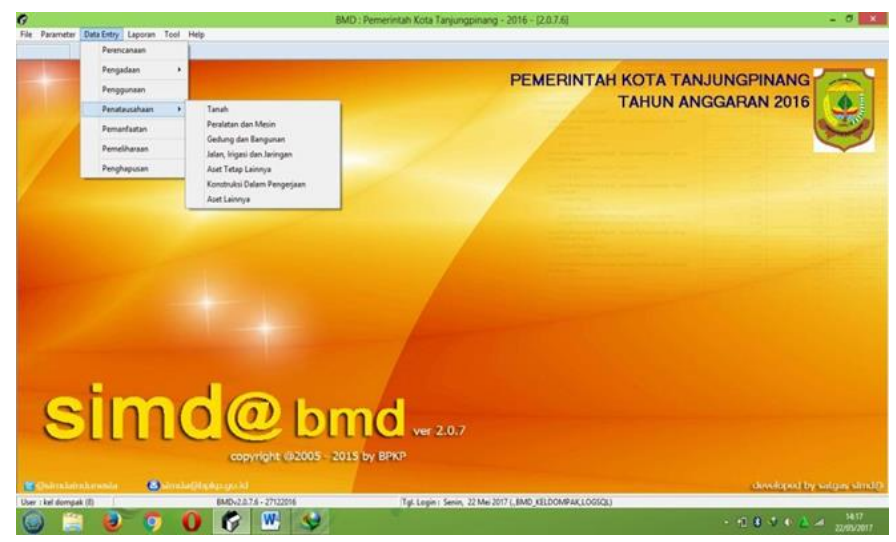

Source: Application SIMDA BMD village in Tanjungpinang, 2017

Prior administration do so prior to opening the Data Entry roomates there are items the planning, procurement, usage, administration, use, maintenance, removal. After that, further to select items of administration of the which there are items of equipment and machinery after the open, it can proceed to the procurement of goods to the way it works it can be seen in the figure below;

\section{FIGURE 3}

Display Procurement of goods In-App BMD SIMDA

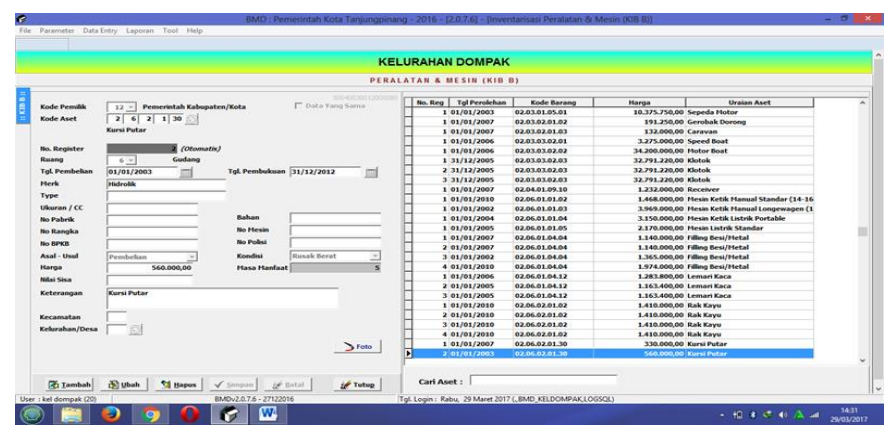

Source: Application SIMDA BMD Village in Tanjungpinang, 2017

For the procurement of tools and machines it can be seen in the image above there are items that should be on the content of the code owner is the City of Tanjungpinang after the it input code assets romates Reviews These system code assets already in application, it is automatically register number with the which goods are to be purchased, then the brand, type, size, No. factories, pricing, sub-district and village names are required. If all items are already in the content based on the goods to be purchased, it can be seen to the right of the item, it can be seen No. registration, the date of acquisition, the item code, price and descriptions of assets that have been filled systematically. After a barrage of inputting eat the produce of input will be submitted to DPPKAD to sync your data in the item price. 
For internal control SIMDA-BMD in Data Processing Regional Property villages in Tanjungpinang, the control application is applied which includes the input control, control processes and controls output.

a. Control input

Data from the procurement of BMD or from the inventory and then put into application, Control of the source document has been done at the time of the procurement process. Input error correction can be done by performing the procedure change data, correction and change conditions.

b. Process control

This control basically been integrated in the system, such as grouping items based on their classification. There is a rejection function automatically when inputting the data is not in accordance with the classification of BMD.

c. Output control

output control performed by verification by each village as an entity accounting and Assistant Property Manager as the reporting entity at the time of preparation of the Report of BMD. If the output is generated correctly and accurately so that information can be used as the preparation of reports, but if there are errors then do the correction process.

In keeping with the application on SIMDA BMD in the village of in Tanjungpinang if an when the application SIMDA BMD down then there will be improvement of BPKAD application, to anticipate the application is down then BPKAD always upgrade SIMDA application version BMD every year.

\section{Participation}

Through participation or involvement, meaning that participation is a form of communication, communication means there is a flow of information between the actors involved in the urban village by government agencies in each interact Tanjungpinang city so that it can determine the success of the implementation of E-Government which has been implemented through multi-user technology and technology clien/server. Participation village employees in Tanjungpinang is expected in the implementation of egovernment applications. participation made urban employees intended to determine the benefits accrue to employees village and the extent to which the success of the implementation of the e-government applications.

Village employees for participation in Tanjungpinang is good which can be seen from the enthusiasm and interest of employees of the Village in the Village running applications, where the application is to improve accessibility data presented in the application is presented accurately and quickly. See already their participation in running the application villages in Tanjungpinang city with related agencies, it can cause a rapid flow of communication.

\section{Human Resources}

Human resources (HR) is a resource capacity especially village government apparatus Tanjungpinang so by increasing human resources is factor that determines even the key to the successful implementation of e-government implementation in Sub Tanjungpinang.

For Human Resources (HR) Village in Tanjungpinang already well where visible from villages staff who can operate the application of e-government, it is supported by staffing villages that are reliable in the field of data processing and information electronically so that the operator of the application can be run with good. As for the socialization of employee village in the running of e-government villages in the town tanjugpinang been done by Government Agencies Tanjungpinang but the socialization of all the applications in this district just walk one time, while for new employees who run this application, the learning for the operator of such applications via the previous application. Socialization is very important which provide education specifically regarding egovernment applications to employees village in Tanjungpinang. One must in right again in the capacity of human resources required to manage each of these applications so that the backup employee first employee sick time, or pension then quickly replaceable.

\section{Government Support (Budget and Funds)}

Availability and consistency of this budget is a great support to develop e-government applications villages in Tanjungpinang city already be applied. Therefore, government support occupy a very important role if government support is not given then ensured the implementation of e-government applications village in Tanjungpinang also will not run smoothly. The government support involves BPKAD (Finance and Asset Management Agency Region), of instansi this always a good favor of budgets in computer maintenance and repair applications from existing applications implementation is in the Village of Tanjungpinang.

Financial constraints in the implementation of egovernment applications can be influential in the organization of work processes electronically. The main challenge for the government is capable provide telecommunications infrastructure such as computers, the Internet and telecommunications infrastructure maintenance. so with this condition should always strategize government in building a comprehensive e-government network despite limited funds.

Regarding the government's support for the implementation of e-government applications in the Village in Tanjungpinang is now visible through the budgetary support of the budget where the budget in the allotment of telecom infrastructure facilitate village such as computers, the Internet and the infrastructure maintenance. Government support in the implementation of e-government applications village in Tanjungpinang is basically not optimal, due to the provision of the budget in the application and development of egovernment through other applications that can be run every 
village in Tanjungpinang has not been a top priority for Government agencies Tanjungpinang.

\section{Regulation}

SIMDA BMD application program is an application program that is used to perform the process of asset management area (BMD) are computerized which aims to harmonize the application of management policies BMD in accordance with applicable regulations. Can be seen groove legal basis concerning the application SIMDA BMD in the flowchart below:

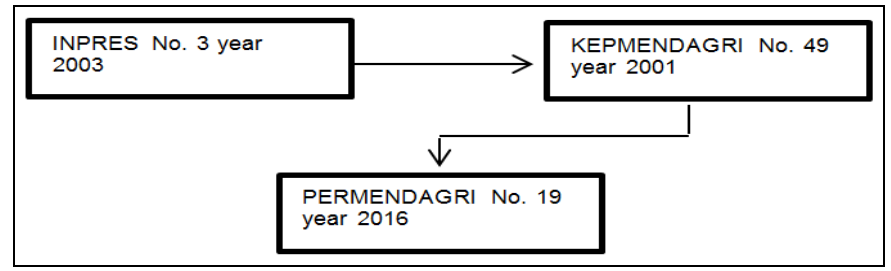

Source: Processed Data Flow Application Basic Regulation SIMDA BMD, 2017

Underlying BMD application deployments SIMDA villages in Tanjungpinang city at the central level, namely Presidential Instruction No. 3 of 2003 on national policy and strategy development of e-government. Furthermore, the application SIMDA BMD developed through Kepmendagri No. 49 of 2001 on local goods management information systems and continued with Regulation No. 19 Year 2016 on Guidelines for Regional Property Management.

With the Kepmendagri and the Regulation in particular to organize and manage applications SIMDA BMD in general. Based on the above presentation, that the availability of basic laws that made reference to build applications SIMDA BMD village in Tanjungpinang, at the central level is sufficient it is because of the regulations that support the development and develop SIMDA BMD at the Village in Tanjungpinang.

\section{Inhibiting factors in the implementation of applications simda bmd villages in Tanjungpinang}

In general, application implementation village in Tanjungpinang already runs well, although it is undeniable problems in applications in the Village found. Subject existing problems related to the application of the application SIMDA BMD village there are obstacles in their applicability. Barriers were found in the implementation of applications SIMDA BMD can not be separated from the findings of the authors in the field through interviews with informants who operate the application and the Secretary of the Village of the inhibiting factor in the implementation of e-government applications village in Tanjungpinang which there are problems in input for application SIMDA BMD is there already was a selection menu for inpor and export data but can not be used properly because the application is still offline. in input data is still working twice as well in the village and this BPKAD really takes much less an error in the financial and goods input the village clerks must readjust and if it is appropriate and then submitted to BPKAD. whereas the urban village to import data must use flasdisk services to inform BPKAD.

\section{CONCLUSIONS}

The BMD SIMDA application system have function to assist the village in Tanjungpinang in carrying out the task of procurement planning, use, administration, maintenance, utilization, elimination of regional goods and accounting items automatically. on the mark with his pitch-mapping item code, code and code assets expenditure in this application. The obstacles in the operator of this application could not used id system inpor and export of data because the application is still offline, to export and inpor this data is the village using intermediaries flash disc to inform to BPKAD if an error occurs then the data in input repeated in the Village and is very time consuming long time.

In addition for the existing telecommunications infrastructure in sub-districts throughout Tanjungpinang city either from a computer and internet networks are adequate in running applications in the villages in the city of Tanjungpinang. Village employee participation in Tanjungpinang is good which can be seen from the enthusiasm and interest of employees of the Village in the Village running applications, where the application is to improve acceptability data presented in the application is presented accurately and quickly. As for the For Human Resources (HR) Village in Tanjungpinang already well where visible from villages staff who can operate the application of e-government, it is supported by staffing villages that are reliable in the field of data processing and information electronically so that the operator of the application can be goes well. Regarding the government's support for the implementation of e-government at the village in Tanjungpinang is now visible aid budget through budget funds which this budget in the allocation to facilitate telecommunications infrastructure village such as a computer, an internet connection and maintenance infrastructure.

\section{REFERENCES}

[1] Aditya Ayu Oktavya 2015. Application (Electronic Government) EGovernment On Tax Office Primary In Service Delivery in the Office of Boating. Government Science Journal Vol 3 No 3 Year 2015 Mulawarman.

[2] Afifuddin And Beni Ahmad. 2009. Qualitative Research Methodology.Bandung: Pustaka Setia.

[3] Budiman S, et al, 2017. Comparative E-Government Is Indonesia And Malaysia, Utilization Of Government Online Service. Proceedings of the International Conference On Government Humanities Social Science. Palembang, 2017. The Ministry of Communications and Informatics. EGovernment Blueprint For Local Government Institutions.

[4] Indrajit, Richardus Eko. 2002. Building E-Government Applications.Yogyakarta: Andi.

[5] Kusuma Dewi, Agus Wahyu W. 2012. Implementation of E-Government System in Improving Clean Good Government Ind'Indonesia.Jeam Journal Vol Xi No. 1/2012. University of Jember. 
[6] Kadir, Abdul. 2007. Introduction to Information Systems.Yogyakarta: Andi.

[7] Kumorotomo Wahyudi, 2004. Management Information Systems. Yogyakarta: Gadjah Mada University Press.

[8] Mcleod, 2010. Management Information Systems. Jakarta: Selemba Four.

[9] N. Madison Ngafeesoon, Mohammad I. Merhi, 2013. E-Government Diffusion: Evidence From The Last Decade. International Journal of Electronic Government Research,9 (2) 1 to 18 April-June 2013. The University Of Texas Pan American, Edinburg. Tx, USA
[10] Machsun Rifauddin, 2017. Management of Technology Based Electronic Archive. Al-Hikmah Khizanah Journal of Library Science, Information and Archives, 4 (2), 168-178 UIN Sunan Kalijaga, Yogyakarta.

[11] Susanto Azhar, 2007. Management Information Systems. Bandung: Lingga Jaya.

[12] Presidential Instruction No. 3 of 2003 on the National Development Strategy and E-Government in Indonesia.

[13] Ministry of Domestic Affairs 49 of 2001 on Regional Goods Management Information System.

[14] Regulation of the Minister of Interior No. 19 Year 2016 on Guidelines for Regional Property Management. 